\title{
Cyclone trends constrain monsoon variability during late Oligocene sea level highstands (Kachchh Basin, NW India)
}

\author{
M. Reuter ${ }^{1}$, W. E. Piller ${ }^{1}$, M. Harzhauser ${ }^{2}$, and A. Kroh ${ }^{2}$ \\ ${ }^{1}$ Institute for Earth Sciences, University of Graz, Heinrichstrasse 26, 8010, Graz, Austria \\ ${ }^{2}$ Department of Geology and Palaeontology, Natural History Museum Vienna, Burgring 7, 1010 Vienna, Austria
}

Correspondence to: M. Reuter (markus.reuter@uni-graz.at)

Received: 13 December 2012 - Published in Clim. Past Discuss.: 24 January 2013

Revised: 15 July 2013 - Accepted: 17 July 2013 - Published: 4 September 2013

\begin{abstract}
Climate change has an unknown impact on tropical cyclones and the Asian monsoon. Herein we present a sequence of fossil shell beds from the shallow-marine Maniyara Fort Formation (Kachcch Basin) as a recorder of tropical cyclone activity along the NW Indian coast during the late Oligocene warming period $(\sim 27-24 \mathrm{Ma})$. Proxy data providing information about the atmospheric circulation dynamics over the Indian subcontinent at this time are important since it corresponds to a major climate reorganization in Asia that ends up with the establishment of the modern Asian monsoon system at the Oligocene-Miocene boundary. The vast shell concentrations are comprised of a mixture of parautochthonous and allochthonous assemblages indicating storm-generated sediment transport from deeper to shallow water during third-order sea level highstands. Three distinct skeletal assemblages were distinguished, each recording a relative storm wave base. (1) A shallow storm wave base is shown by nearshore molluscs, reef corals and Clypeaster echinoids; (2) an intermediate storm wave base depth is indicated by lepidocyclinid foraminifers, Eupatagus echinoids and corallinacean algae; and (3) a deep storm wave base is represented by an Amussiopecten bivalve-Schizaster echinoid assemblage. These wave base depth estimates were used for the reconstruction of long-term tropical storm intensity during the late Oligocene. The development and intensification of cyclones over the recent Arabian Sea is primarily limited by the atmospheric monsoon circulation and strength of the associated vertical wind shear. Therefore, since the topographic boundary conditions for the Indian monsoon already existed in the late Oligocene, the reconstructed long-term cyclone trends were interpreted to reflect monsoon variability during the initiation of the Asian monsoon system. Our
\end{abstract}

results imply an active monsoon over the Eastern Tethys at $\sim 26 \mathrm{Ma}$ followed by a period of monsoon weakening during the peak of the late Oligocene global warming $(\sim 24 \mathrm{Ma})$.

\section{Introduction}

Cyclones are one of the most devastating weather phenomena that affect tropical coasts (Henderson-Sellers et al., 1998). For this reason, attempts to relate trends in tropical cyclone intensity and frequency with global change have become a challenging subject in recent years (e.g. Goldenberg et al., 2001; Webster et al., 2005; Klotzbach, 2006; Holland and Webster, 2007; Elsner et al., 2008; Emanuel et al., 2008; Vecchi and Knutson, 2008; Evan et al., 2011). Although future predictions consistently indicate that greenhouse warming will cause the globally averaged intensity of tropical cyclones to shift towards stronger storms (Solomon et al., 2007), the limited instrumental record and deficient availability and quality of global historical records impede extensive analyses of the natural cyclone variability in most of the tropical cyclone basins (Henderson-Sellers et al., 1998). Therefore, it remains uncertain whether current changes in tropical cyclone activity have exceeded the variability expected from natural causes (Knutson et al., 2010). The Indian Ocean including the Arabian Sea and the Bay of Bengal is of particular concern because of the high population density along the coastline (Charabi, 2010). In the Arabian Sea, most storms tend to be small and dissipate quickly because the Indian summer monsoon and associated vertical wind shear effectively prevent large storms from developing at the time sea surface temperatures (SST) are at their maximum 
(Evan and Camargo, 2011). However, the wind circulation pattern over the northern Arabian Sea has changed over the last $30 \mathrm{yr}$ allowing stronger storm development (Evan et al., 2011). As a result, the Saurashtra and Kachchh regions at the northwestern coast of India have been increasingly subjected to severe cyclonic storms in recent years (Nigam and Chaturvedi, 2006). This change of atmospheric circulation is related to significant reductions in storm-ambient vertical wind shear in the troposphere during the pre-monsoon season (May-June; Evan et al., 2011; Wang et al., 2012). Evan et al. $(2011,2012)$ recently attributed this reduction of pre-monsoon vertical wind shear to the dimming effects of anthropogenic aerosols in the atmosphere over India and the Indian Ocean. However, this relationship is still under debate. Wang et al. (2012) argue that the decline in vertical wind shear more likely results from a systematic shift in the onset of summer monsoon, which may be caused by enhanced land-sea thermal contrast between the Asian landmass and the equatorial Indian Ocean either due to anthropogenic warming or as part of a natural cycle.

In the geological record storm events have been preserved as tempestite beds and temporal variations in their abundance and thickness provide information about palaeostorm intensities and frequencies (Brandt and Elias, 1989; Long, 2007). Here we present a shallow marine tempestite sequence from the Maniyara Fort Formation in the Kachchh Basin (Gujarat, NW India) as a record for cyclone activity during the late Oligocene. This episode is of peculiar importance for the Asian climate evolution because the atmospheric circulation changed from zonal to monsoon dominant at the OligoceneMiocene boundary (Sun and Wang, 2005; Guo et al., 2008). The insufficient time constraint of the mainly continental monsoon records, however, permits neither the exact timing of this important climate change nor the linkage of spatial and temporal climate patterns to Cenozoic global ice-volume and temperature changes as recorded in the deep-sea $\delta^{18} \mathrm{O}$ records (Sun and Wang, 2005; Guo et al., 2008). The herein presented integrated bio- (larger benthic foraminifers) and sequence stratigraphic correlation of tempestite shell beds with the global deep-sea isotope record (Zachos et al., 2001, 2008) relates regional atmospheric variability over NW India to long-term global climate trends. The results are important because they represent the first proxy data for long-term atmospheric dynamics over the Eastern Tethys during the late Oligocene.

\subsection{Geological setting and locality}

The Kachchh Basin is a peri-cratonic rift basin at the western passive continental margin of India (Biswas, 2005) (Fig. 1). It opened since the Late Triassic-Early Jurassic due to the break-up of the Gondwana supercontinent and the subsequent counter-clockwise north drift of the separated Indian subcontinent (Biswas, 1982, 1987; Ali and Aitchison, 2008). A $3000 \mathrm{~m}$-thick succession of predominantly siliciclastic

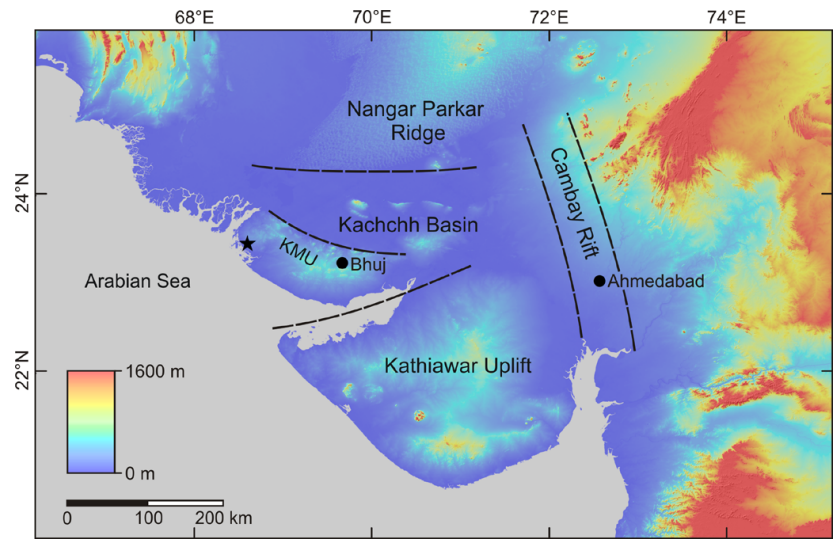

Fig. 1. Digital elevation model of northwestern India (Jarvis et al., 2008) showing the main structural geological elements of the Kachchh Basin. The black asterisk locates the studied outcrop at Bermoti $\left(23^{\circ} 27^{\prime} 45^{\prime \prime} \mathrm{N}, 68^{\circ} 36^{\prime} 07^{\prime \prime} \mathrm{E}\right)$ on the Kachchh Mainland Uplift (KMU).

shallow-marine and fluvio-deltaic sediments was deposited during the synrift stage (Biswas, 1982, 1992, 2005). The rifting ceased in the Late Cretaceous due to the beginning collision of India and Asia. After a phase of effusive Deccan Trap volcanism (Biswas and Deshpande, 1973; Saunders et al., 2007), uplift occurred along the entire western Indian rifted margin during the Eocene-Oligocene (Shanker, 2001). It was initiated by the commencement of subduction of oceanic crust below the Tibetan Plate, which stopped the free drift of the subcontinent (Shanker, 2001). The resultant compressive stress regime caused the uplift and tilting of tectonic blocks in the Kachchh Basin (Biswas, 2005). The largest one was the SW-tilted Kachchh Mainland Uplift (KMU), which extends over $150 \mathrm{~km}$ in northwest-southeast direction (Fig. 1).

The studied outcrop is located along the bed of the Bermoti River in the surrounding of the village Bermoti $\left(23^{\circ} 27^{\prime} 45^{\prime \prime} \mathrm{N}, 68^{\circ} 36^{\prime} 07^{\prime \prime} \mathrm{E}\right.$; Fig. 1) and represents the type locality of the Oligocene Maniyara Fort Formation (Biswas and Raju, 1971; Biswas, 1992). The exposed sedimentary succession was deposited in marginal marine, littoral to shallow inner shelf environments on the $<10^{\circ}$ inclined homoclinal dip-slope ramp of the KMU (Biswas, 1992; Harzhauser et al., 2009). According to Biswas (1992), the Maniyara Fort Formation includes four informal lithostratigraphic members: (1) the Basal Member, (2) the Lumpy Clay Member, (3) the Coral Limestone Member, and (4) the Bermoti Member (Biswas, 1992). The Basal Member comprises alternating beds of foraminiferal limestone, glauconitic siltstone and calcareous, gypsiferous claystone. The Lumpy Clay Member includes calcareous, lumpy claystones with thin intercalated limestone and marl beds. The Coral Limestone Member is defined as a succession of biosparites and glauconitic biomicrites. Calcareous claystones are intercalated in its lower part, while its upper part is characterised by small coral 
bioherms. The boundary to the Bermoti Member is marked by the sudden appearance of glauconite in ochre coloured sandstones with abundant vertebrate remains. The carbonatic Maniyara Fort Formation is overlain by siliciclastics of the Khari Nadi Formation of Aquitanian age (Biswas, 1992). The siliciclastic sedimentation prevailed until present-day (Biswas, 1992).

\section{Methods}

Bermoti River section was measured bed-for-bed. The primary dataset consists of sedimentological information gathered through field observations and 50 thin sections $(5 \mathrm{~cm} \times 5 \mathrm{~cm})$. Sedimentological data include lithology, sedimentary texture, sedimentary structures, nature of bedding and bedding contacts, fossil content, and lateral variability. Due to their large size, the relative abundance of the major components in the shell beds have been estimated in the field.

\section{Results}

The measured section has a total thickness of about $31 \mathrm{~m}$ and represents the upper part of the Coral Limestone Member $(6 \mathrm{~m})$ and the Bermoti Member $(12 \mathrm{~m})$ of the carbonatic Maniyara Fort Formation as well as the lower part of the siliciclastic Khari Nadi Formation (13 m) (Fig. 2).

\subsection{Maniyara Fort Formation}

Generally, the Maniyara Fort Formation is characterised by a partly dolomitic succession of bioturbated wackestones, packstones and marls alternating with massive, matrix-rich skeletal rudstones of 0.2 to $0.8 \mathrm{~m}$ thickness (Fig. 2). Typically, the skeletal rudstones are poorly sorted and dominated by variable amounts of larger benthic foraminifers, molluscs, echinoids, bryozoans and corallinaceans in a bioclastic packstone matrix. The skeletal components are randomly orientated and bivalve shells are always disarticulated. Usually, these shell beds form vast sheets, which can be exposed over some $100 \mathrm{~m}^{2}$ in the outcrop without showing a difference in thickness or facies (Fig. 3a). The contact to the underlying sediments is always sharp.

\subsubsection{Coral Limestone Member}

In the lower part of the Coral Limestone Member the skeletal rudstone sheets are mainly formed by lepidocyclinids up to $2 \mathrm{~cm}$ in diameter and biconvex discoidal in shape (Fig. 3b); nummulitids, gastropods (e.g. Ampullinopsis crassatina), pectinids (Aequipecten, Fig. 3b), coral fragments (Acropora) and irregular echinoids (Clypeaster, Eupatagus) are associated (Fig. 2). Four species of Nummulitidae (Nummulites aff. vascus, N. fichteli, N. sublaevigatus, Operculina complanata) and one of Lepidocyclinidae (Eulepidina dilatata) were identified in the larger foraminiferal rudstones of the Coral Limestone Member. The upper surface of the larger foraminiferal concentrations can be encrusted by several decimetre high coral heads (Fig. 3c) or colonised by tubes of the teredinid bivalve Kuphus (Fig. 2). Large, horizontal burrow systems of decapods can also occur at the top of larger foraminiferal deposits (Fig. 3d). The uppermost lepidocyclinid limestone bed in the Coral Limestone Member was deposited above a ferruginous crust and is characterised by abundant corallinaceans and detritic glauconite in a muddy dolomitic matrix. In contrast to all other sheet-like shell beds in the Maniyara Fort Formation, this bed has a wedge-shaped profile, which is decreasing in thickness from $1 \mathrm{~m}$ in the NE to $0.25 \mathrm{~m}$ in the $\mathrm{SW}$ over a distance of $60 \mathrm{~m}$ (Fig. 2).

The upper part of the Coral Limestone Member is characterised by small patch reefs (Fig. 2). They are interfingering with fine-grained fossiliferous platy limestones that contain articulated bivalves (Aequipecten, Cyathula, Lucinoma, cardiids, tellinids), solitary corals and abundant ostracods (Bairdia). Notably, the surface of the patch reef at the top of the Coral Limestone Member is intensively bored by bivalves and encrusted by corallinaceans. This patch reef is also surrounded by a skeletal rudstone composed of bivalves (cardiids, tellinids, Lucinoma, Cyathula, Aequipecten), gastropods, irregular echinoids (Echinocyamus bernaniensis: abundant, Eupatagus: rare), coral clasts as well as rare larger benthic foraminiferal tests (Nummulites, lepidocyclinids) of small size.

\subsubsection{Bermoti Member}

The Bermoti Member starts with a yellow, $1.25 \mathrm{~m}$-thick dolomite with detritic glauconite and ferriclastic sand content (Fig. 2). It is overlain by a $40 \mathrm{~cm}$-thick, dolomitic sandy (ferriclast sand) rudstone with gastropods (e.g. Ampullinopsis crassatina, Campanile pseudoobeliscus, Cerithium bermotiense, Dilatilabrum sublatissimum, Persististrombus radix, Lyria (Indolyria) maniyaraensis; see Harzhauser et al. (2009) for the full list), bivalves (Aequipecten, Cyathula), echinoids (Clypeaster sowerbyi: abundant, Eupatagus singhi: rare, Prionocidaris: common), coral clasts, small Nummulites (rare), bryozoans and vertebrate bones. Remarkable is the abundant occurrence of articulated crabs (Palaeocarpilius rugifer, Neptunus wynneanus) and the presence of nautilids. The upper surface of this bed is covered by a thin ferruginous crust (Fig. 2). Above follows a $2 \mathrm{~m}$-thick unit of well-sorted, brown ferriclastic sandstone with a $15 \mathrm{~cm}$-thick shell bed in the upper part. It is dominated by a gastropod fauna, which is similar to that of the previous shell bed (Harzhauser et al., 2009). Echinoids (Clypeaster, cidaroids), pectinid bivalves (Aequipecten, Amussiopecten) as well as lepidocyclinids and vertebrate bones are further characteristic biotic constituents. The sandstones are overlain by a $90 \mathrm{~cm}-$ thick dolomitic wackestone with mass-occurring Bairdia ostracods and in situ Kuphus tubes at the top. It is covered by a 


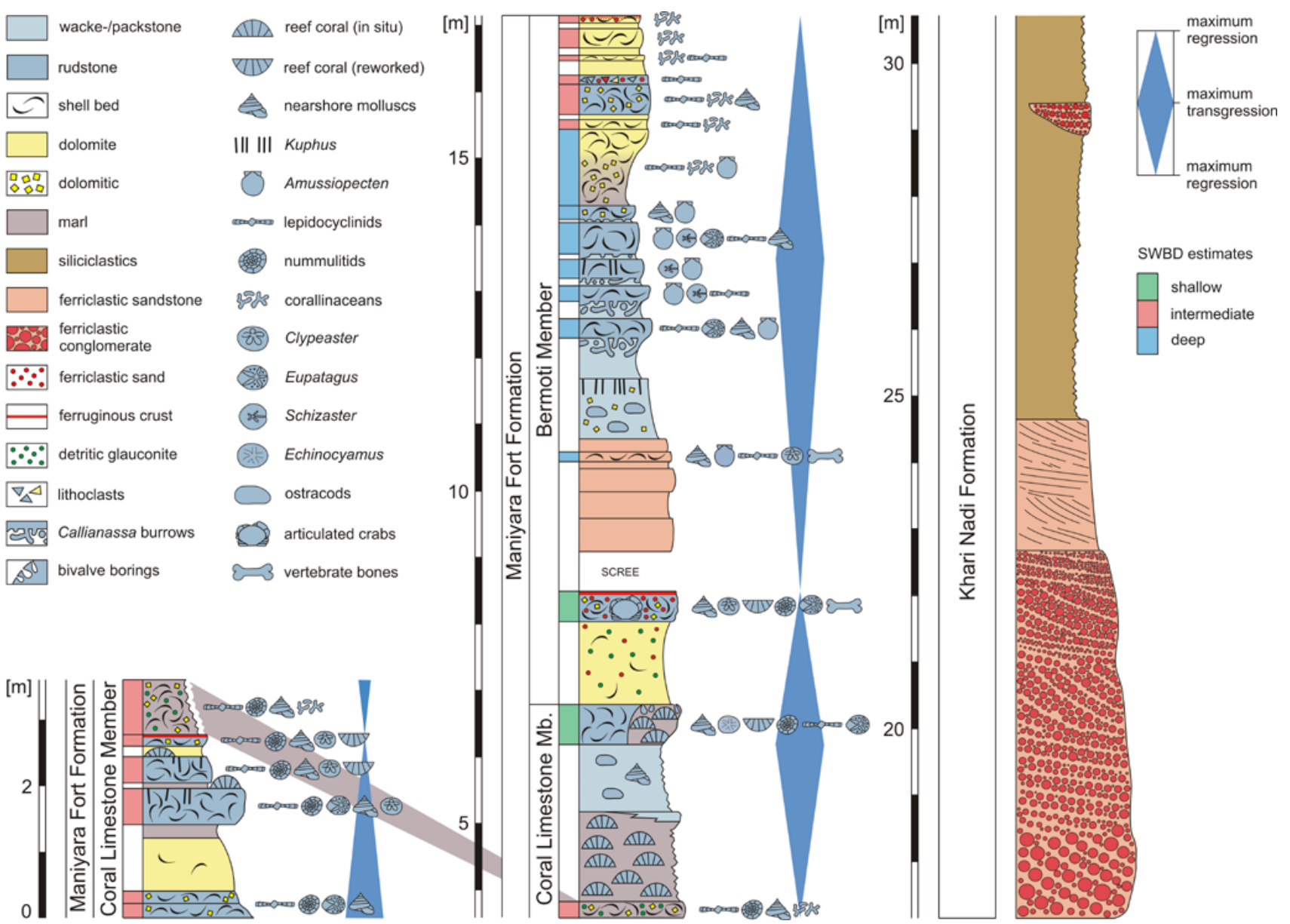

Fig. 2. Bermoti River section. Lithological log, lithostratigraphy (Biswas, 1992), transgressive-regressive cycles and storm wave base depth (SWBD) estimates. The components in the tempestite skeletal assemblages are ordered after their abundance (decreasing from left to right); SWBD estimates refer to Fig. 4.

$2 \mathrm{~m}$-thick wackestone-skeletal rudstone alternation (Fig. 2). Amussiopecten and irregular echinoids (Schizaster sufflatus, Eupatagus) dominate the skeletal assemblages in the rudstones (Fig. 3e). Lepidocyclinids and gastropods are associated. Eupatagus can be very frequent in lepidocyclinidrich deposits (Fig. 3f). The gastropod faunas are similar to that at the base of the Bermoti Member. Callianassa burrows at the contact to the underlying wackestones are filled with coarse skeletal debris. In situ tubes of Kuphus can occur at the top of rudstone beds. In the upper part, the Bermoti Member shows again dolomitization (Fig. 2). The skeletal assemblages of the rudstone sheets in this part of the section are dominated by biconvex discoidal lepidocyclinids (Eulepidina dilatata; $2 \mathrm{~cm} \varnothing$ ) and corallinacean branches. A thin $(5 \mathrm{~cm})$ bed of poorly sorted, bioclastic lithoclast rudstone is intercalated in the upper part of this unit. It is well winnowed and dominated by angular lepidocyclinid limestone lithoclasts $<1.5 \mathrm{~cm}$. Dolomite clasts, ferricrete clasts and quartz grains are present as well. The top of the Bermoti Member is represented by a red mottled dolomite with ferriclastic sand (Fig. 2).

\subsection{Khari Nadi Formation}

The Khari Nadi Formation starts with a $5 \mathrm{~m}$-thick, brown pebbly-cobbly, grain-supported conglomerate composed of well-rounded and polished ferricrete grains and single pebbles of white agate (Fig. 2). The conglomerate exhibits clinoforms dipping $19^{\circ}$ to the SW. Upsection and towards the $\mathrm{SW}$ it passes into fine-grained siliciclastic sediments (sandy silts, silty clays, fine-grained sandstones).

\section{Discussion}

\subsection{Biostratigraphy}

Biswas (1992) assumed a Rupelian age for the Coral Limestone Member based on the presence of Eulepidina dilatata and Nummulites fichteli and a Chattian age for the Bermoti Member due to its typical fauna. In fact, the presence of $N$. fichteli, $N$. aff. vascus, $N$. sublaevigatus and E. dilatata indicates an early Chattian age (SBZ22B of Cahuzac and 

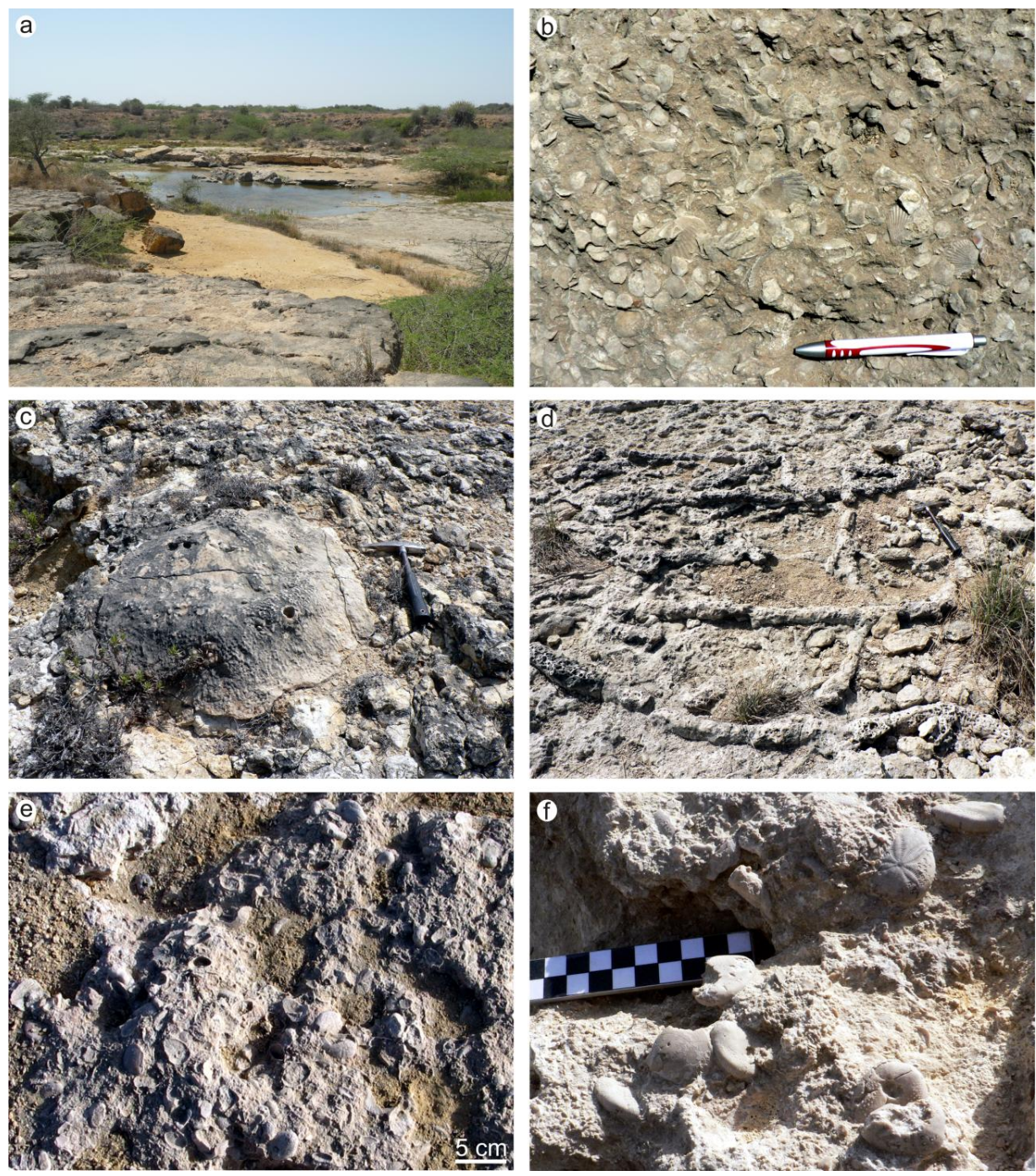

Fig. 3. Field aspects of tempestite facies in the Maniyara Fort Formation. (a) Vast tempestite shell beds exposed in the bed of Bermoti River. (b) Large lepidocyclinids are the dominant constituent of tempestite deposits in the lower part of the Coral Limestone Member. (c) Massive coral colony encrusting the surface of a tempestite shell bed; Coral Limestone Member. (d) Extensive decapod burrow system at the top of a larger foraminiferal shell bed; Coral Limestone Member. (e) Mass accumulations of irregular echinoids characterise the tempestite deposits of the Bermoti Member. (f) Concentration of Eupatagus coronas in lepidocyclinid rudstone facies; Bermoti Member. One square on the graphic scale is $1 \mathrm{~cm}$.

Poignant, 1997) for the lower part of the Coral Limestone Member while the absence of Nummulites and the presence of $E$. dilatata suggest a late Chattian age (SBZ23 of Cahuzac and Poignant, 1997) for the upper part of the Bermoti Member (Fig. 4). The Khari Nadi Formation is dated to the Aquitanian by the occurrence of Miogypsina tani (Biswas, 1992).

\subsection{Depositional environments}

For the Maniyara Fort Formation, a shallow restricted inner ramp environment is indicated by the occurrence of in situ Kuphus tubes (Reuter et al., 2008), an individual-rich, monotypic (Bairdia) ostracod assemblage in the micrite-rich facies
(Kornicker, 1961) and common dolomitization (Fig. 2). The formation of dolomite is considered to be an early diagenetic process because it is restricted to distinct beds and within close stratigraphic proximity to emergence horizons. Less restricted shallow marine conditions are documented by in situ coral patch reefs.

Laterite soils and their reworking products are well known from the Cenozoic succession of Kachchh (e.g. Biswas, 1992; Valeton and Wilke, 1993; Valeton, 1999). Accordingly, pedogenesis during partial emergence of the KMU and denudation of lateritic soils that formed on exposed Deccan Trap basalts during the Eocene (Valeton, 1999) are documented by ferruginous crusts (relics of laterite soils) and 


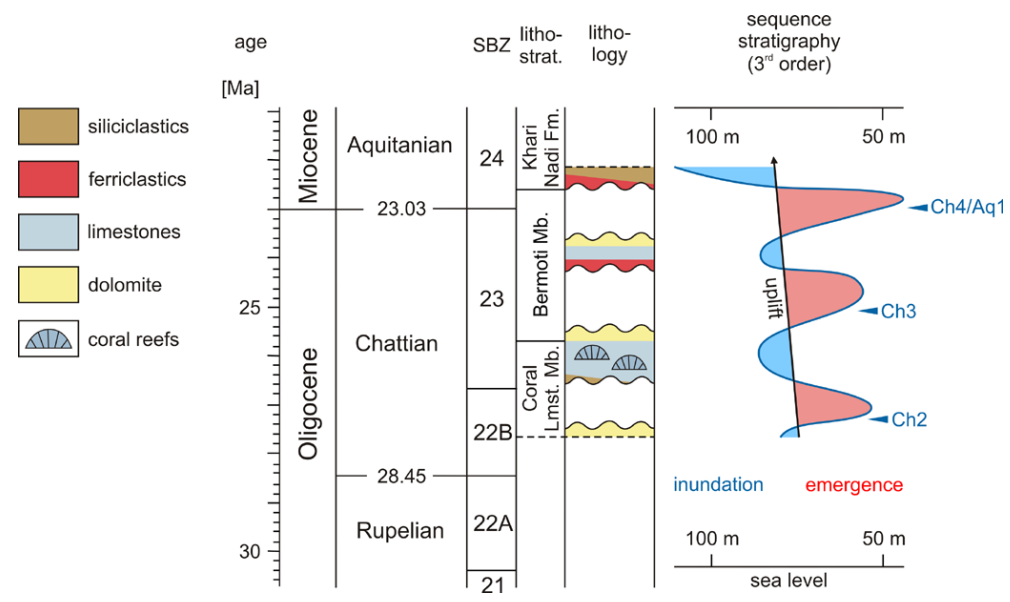

Fig. 4. Stratigraphic correlation of Bermoti River section with the shallow benthic foraminifera zones (SBZ) of Cahuzac and Poignant (1997), third-order sequences of Hardenbol et al. (1998) and global chronostratigraphy (Gradstein et al., 2012). Lithostratigraphy according to Biswas (1992).

red motteling as well as intercalations of ferriclastic sand at the base and top of the Bermoti Member (Fig. 2). The ferriclastic conglomerate at the base of the Khari Nadi Formation (Fig. 2) shows the foreset/topset pattern of a SW prograding Gilbert-type delta. Ferriclastic components typically represent nodules or fragments of nodules with pedorelics suggesting a laterite origin. Associated pebbles of white agate indicate that the ferriclasts originate from the erosion of lateritic crusts that developed on weathered Deccan Trap basalts.

The occurrences of glauconite grains seem to contradict an episodically emerged shallow ramp setting since this mineral is commonly considered to be a sensitive indicator of low sedimentation rates in outer shelf or even greater depths (> 100 m; Amorosi, 1997; El Albani et al., 2005). Because the glauconite is always associated with ferruginous crusts/ferriclastic sand and dolomite in the Bermoti River section (Fig. 2), it is, however, more likely that it derived from the reworking of the glauconite-bearing sediments from the Basal Member of the Maniyara Fort Formation than having formed autochthonously. Consistent with this interpretation is the documentation of considerable concentrations of reworked glauconite grains in a variety of shallow-marine environments which are either due to subaerial shelf exposure during relative sea level fall or due to remobilization of glauconite by storms and tidal currents during relative sea level rise (Amorosi, 1997). Such detritic glauconite is preferentially accumulated within coarse-grained, high-energy deposits, interbedded with glauconite-free, low-energy sediments (Amorosi, 1997) like in the Bermoti River section. In contrast, autochthonous glauconite is mostly concentrated at the tops of coarse-grained units in transgressive shallow water successions because glauconitization commonly postdates high-energy sedimentation (Amorosi, 1997). This is, however, not observed in the studied section.

\subsection{Sequence stratigraphic correlation: effects of sea level and tectonic uplift on sedimentation}

Due to its position in the inner Kachchh Basin (Fig. 1) the KMU was isolated from coarse-grained terrigenous discharge, which may have entered the basin from the continent. Only clay minerals had the chance to arrive on the carbonate ramp as suspension load from the basin margins. Therefore a coarse-grained terrigenous fraction must have had local sources in the area of the KMU during relative sea level lowstands. Moreover, the very shallow depositional environments throughout the Maniyara Fort Formation show that even a few metres sea level fall must have resulted in the emergence of the KMU ramp at the Bermoti River locality. Although the amplitudes of the late Oligocene third-order sea level cycles may vary on a regional scale (e.g. Stocchi et al., 2013), they were in the range of several tens of metres (Kominz and Pekar, 2001; Miller et al., 2005; Hardenbol et al., 1998). The study site could have been flooded therefore only during their highstands (Fig. 4). Dolomitization as well as reworking and input of terrigenous sediment characterise the early and late highstands while more open marine conditions enabled coral reef growth during maximum flooding (Fig. 4). The increasing restriction of the KMU carbonate ramp during the Oligocene, which is displayed by the increasing dolomitization and the disappearance of reef corals towards the top of the Maniyara Fort Formation, documents a decreasing accommodation space due to the advancing uplift of the KMU tilt block (Fig. 4). As a result of this tectonic movement extensive parts of the KMU became permanently exposed in higher elevated areas at the onset of the Aquitanian and the Oligocene and Eocene cover was removed. This unroofed the about $3000 \mathrm{~m}$-thick siliciclastic Mesozoic core of the KMU and its siliciclastic weathering products suffocated the carbonate ramp. Since that time the shallowmarine carbonate factory has not been able to recover in the 
Kachchh Basin due to a steady input of siliciclastic sediments.

For sequence stratigraphic interpretation (Fig. 4), we follow Hardenbol et al. (1998) since their charts result from global composite stratigraphic records and are well calibrated to the GTS2012 (Gradstein et al., 2012). Possibly better constrained sea level estimates derived from backstripping analysis are confined to the northern Atlantic margin (e.g. Van Sickel et al., 2004; Kominz et al., 2008) and may not be applied to the Eastern Tethys region. Based on larger benthic foraminiferal biostratigraphy the studied part of the Maniyara Fort Formation can include the entire Chattian (SBZ22A-SBZ23). The studied sedimentary record includes three unconformities, which can be interpreted to represent three relative sea level lowstands (Fig. 4). The Aquitanian age of the Khari Nadi Formation assigns the unconformable contact to the Maniyara Fort Formation to the Ch4/Aq1 sequence boundary. Due to biostratigraphy, the lowermost unconformity can be either correlated to the Ru4/Ch1 or the $\mathrm{Ch} 2$ sequence boundary. Consequently, the following unconformity can either represent the $\mathrm{Ch} 2$ or $\mathrm{Ch} 3$ sequence boundary. Since no evidence for an amalgamated unconformity exists, the relative sea level lowstand, which is documented by the ferruginous crust at the base of the ferriclastic sandstones in the lower part of the Bermoti Member (Fig. 2), most likely correlates with the $\mathrm{Ch} 3$ sequence boundary. Accordingly, the lowermost unconformity, which is represented by the ferruginous crust in the Coral Limestone Member (Fig. 2) can be correlated with the sea level lowstand that produced the $\mathrm{Ch} 2$ sequence boundary.

\subsection{Shell bed taphocoenoses and deposition}

The skeletal assemblages in the shell bed facies contain substantial amounts of biota, which are completely lacking in the autochthonous micrite-rich facies (gastropods, larger benthic foraminifers, coralline red algae, irregular echinoids, Amиssiopecten; Fig. 2), indicating extensive lateral sediment transport. The highly diverse gastropod faunas derived from shallow nearshore environments (Harzhauser et al., 2009). Giant conchs such as Dilatilabrum sublatissimus for instance are found today in seagrass meadows and sheltered lagoons, where they live partly buried in the soft substrate (Bandel and Wedler, 1987). Accompanying Clypeaster echinoids also occur most commonly in sandy sediments with seagrass patches at present day (Hendler et al., 1995).

Larger benthic foraminifers are the main constituents of shell bed taphocoenoses in the lower part of the Coral Limestone Member and in the upper part of the Bermoti Member (Figs. 2 and 3b). In the latter case they are typically associated with coralline red algae (Fig. 2). Larger benthic foraminifers are apparently susceptible to re-sedimentation as they lack any form of attachment or stabilization after death (Pedley, 1998). Following the idealised ramp profile of Pedley (1998) for the central Mediterranean
Oligocene-Miocene ramps, autochthonous larger benthic foraminiferal facies with coralline red algae extend from the only few metres deep coral patch reef zone towards deeper middle ramp settings. Thereby, the size of the same lepidocyclinid species increases with greater water depth and their shape changes from very inflated to flat. Flat discoidal Lepidocyclina tests with diameters $>3 \mathrm{~cm}$ represent the greatest water depth in this model $(\sim 40-60 \mathrm{~m})$. The smaller size and more biconvex shape of the lepidocyclinids in the Maniyara Fort Formation indicate a shallower palaeodepth at their living place. In the Bermoti River section coronas of the irregular echinoid Eupatagus are most common in lepidocyclinid concentrations (Figs. 2 and 3f). Live Eupatagus is commonly found between 10 and $60 \mathrm{~m}$ water depth on coral sands of the fore reef slope (Mortenson, 1951; de Ridder, 1984; Schultz, 2005, 2009). Although little is known about its ecology, a functional morphological approach suggests that it is shallow burrowing (Kanazawa, 1992). Morphologically similar forms with enlarged spines are capable of rapid re-burial after disturbance, which allows settlement of higher-energy habitats disturbed by wave turbulence.

The skeletal assemblages of the shell beds in the middle part of the Bermoti Member are dominated by Amussiopecten and irregular echinoids (Schizaster sufflatus) (Fig. 2). Mandic and Piller (2001) have shown that shell convexity, thickness and ornamentation of pectinids is related to life style and habitat and can be used as proxies for hydraulic regimes and water depth. The extinct genus Amussiopecten is morphologically very close to the extant Amusium with its type species Amusium pleuronectes. Both are characterised by light and disc-shaped shells often with moderate ribbing indicating a deeper low energy environment (Mandic and Piller, 2001). Modern Amusium preferentially live in few tens of metres water depth. Amusium pleuronectes is most common between 18-40 m water depth (Brand, 2006) and Amusium balloti is typically found in 30-60 m (Himmelman et al., 2009). Accordingly, comparable pectinid shell beds in the Burdigalian of Egypt, characterised by low diversity, thin shells and weak sculpturing, were interpreted to have formed by winnowing in a few tens of metres water depth $(20-40 \mathrm{~m})$ close to the storm wave base (Mandic and Piller, 2001). Schizaster sufflatus is typically associated with the Amussiopecten mass occurrences in the middle part of the Bermoti Member (Fig. 2). Although Schizaster echinoids are reported from more than $350 \mathrm{~m}$ water depth, most Schizaster species occur in inner neritic environments (5$100 \mathrm{~m}$ ) at present-day (Mortensen, 1951). The distribution of Schizaster seems primarily controlled by the availability of suitable soft sediment bottoms. There it clearly prefers habitats with muddy silt to fine sand bottoms, exploiting bacterial and meiofaunal food sources accumulated at the redox discontinuity potential layer (Schinner, 1993). Due to this habitat preference Schizaster is usually found in protected shallow or deeper settings where a sufficiently thick layer of fine-grained sediment is present. Since Schizaster sufflatus is 
always associated with Amussiopecten in the Maniyara Fort Formation a deeper habitat is indicated.

Although the shell bed taphocoenoses contain substantial amounts of deeper water biota, colonization of the shell beds by Kuphus and reef corals (Fig. 3c) clearly indicates that these shells were concentrated in a very shallow inner ramp setting. Bioclast-filled Callianassa burrows below the erosive base of Amussiopecten-irregular echinoid shell beds in the Bermoti Member (Fig. 2) proofs that the extensive sediment transport from deep to shallow water occurred during high-energetic sedimentation events (Wanless et al., 1988; Seilacher and Aigner, 1991). Due to the properties of the stereom, the echinoderm skeleton is easily abraded and transported after death (Chave, 1964). Immediate burial is therefore essential for complete preservation of articulated or lightly skeletonised specimens (e.g. irregular echinoids, Fig. 3e, f) (Kidwell, 1991). Similarly, rapid burial during a catastrophic sedimentation event might also be responsible for the in situ preservation of articulated crabs in the shell bed at the base of the ferriclastic unit (Brett and Seilacher, 1991). The occurrence of in situ Kuphus tubes and large decapod burrows at the top of shell beds (Fig. 3d) reveal a biological overprint that obliterated primary sedimentologic features (Sepkowski et al., 1991). Conspicuously, the surface of the coral patch reef at the top of the Coral Limestone Member, which is flanked by a skeletal rudstone (Fig. 2), is intensively bored by bivalves and encrusted by corallinaceans. This suggests that bioclastic event sedimentation had suffocated the corals at first and later the unconsolidated bioclastic sediment was removed by agitated water from the most elevated part of the buildup so that dead coral surfaces became exposed and subjected to intense bivalve boring and biogenic encrustation.

\subsection{Origin of event deposits: tempestite versus tsunamite}

At the recent coast of Kachchh high-energy wave events, which are capable of eroding sediments in relatively deep water and re-depositing these in shallow water, are caused by tsunamis and tropical cyclones (Nigam and Chaturvedi, 2006). Both processes result in a mixing of skeletal components representing different environments and can form vast shell beds (Kortekaas and Dawson, 2007; Donato et al., 2008). Synsedimentary uplift of the KMU block indicates that tsunamis may have been triggered by seismic activity at the northwestern margin of India, which was related to transpressional tectonics in response to the convergent movement of Asia and India during the late Oligocene (Shanker, 2001; Gunnell et al., 2003; Sheth, 2007). Since most of the research on tsunami deposits focuses on onshore areas and siliciclastic coasts and most established criteria also apply for storm deposits (e.g. Fujiwara and Kamataki, 2007; Morton et al., 2007; Donato et al., 2008; Feldens et al., 2009; Bahlburg et al., 2010; Engel and Brückner, 2011), the identification of tsunamites, in particular in shallow-marine carbonate environments, remains difficult. The shell beds of the Maniyara Fort Formation formed exclusively in a shallow inner ramp setting on the gentle inclined homoclinal KMU ramp. This setting is most intensely affected by erosion of an incoming tsunami wave (Puga-Bernabéu et al., 2007). The subsequent backflow transports the previously eroded sediments basinwards and produces a thick shell-debris bed on the deeper ramp (Puga-Bernabéu et al., 2007) while nearshore backflow sediments have a patchy or channelised distribution (scourand-fill structures; Einsele et al., 1996; Feldens et al., 2009). Since these features are missing, tsunami events cannot account for the extensive shell beds of the Maniyara Fort Formation.

In contrast, coarse-grained (proximal) tempestites can cover extensive areas on shallow ramparts (Seilacher and Aigner, 1991; Rasser and Riegl, 2002; Flügel, 2004). The process of storm sedimentation changes, however, tremendously with the kind of sediments, the physiographic setting, and water depth (Seilacher and Aigner, 1991). Gagan et al. (1990) describe processes of sediment reworking in deep water and re-deposition in shallow water during cyclone Winifred, which are consistent with our observations. The study shows that strong wave oscillation currents resuspended mid-shelf sediment and, combined with unidirectional wind-forced currents, transported it towards the shore and along the shelf. Possibly, the low density skeletons (echinoderms, larger benthic foraminifers) and/or the flattened shape (larger benthic foraminifers, Amussiopecten) of the predominant deeper water components in the shell beds caused a high transport capacity (Mandic and Piller, 2001; Nebelsick and Kroh, 2002) despite of their large grain size. This may explain the low diversity of the skeletal assemblages in the shell beds. Accordingly, calculated threshold shear velocities for large-sized Nummulites confirm that the larger benthic foraminifers can be easily moved by weak wave-driven currents (Jorry et al., 2006). The uppermost larger foraminiferal shell bed in the Coral Limestone Member differs from all other shell beds by its wedge-shaped geometry, a muddy matrix, and the presence of detritic glauconite (Fig. 2). A modern analogue may be represented by the coastal mud wedges, which were produced by Hurricane Andrew at the southwest Florida coast (Risi et al., 1995). These up to $1 \mathrm{~m}$ thick and over $3 \mathrm{~km}$ long sediment wedges formed just seaward of the shoreline as the surge flood water retreated. Consistent with this interpretation, the wedgeshaped shell bed in the Coral Limestone Member formed at the onset of flooding after a sea level lowstand (Fig. 4) and the fine-grained terrigenous matrix and detritic glauconite indicates strong sediment discharge from a close by hinterland. In contrast, the pure carbonatic sheet-like shell concentrations possibly formed when the shallow carbonate ramp was isolated from the hinterland during the inundation episodes (Fig. 4). 


\subsection{Tropical cyclone environment}

Gray (1968) defined the primary environmental factors to be favorable for tropical cyclone formation. These include (1) sea surface temperature, (2) geographic location, (3) environmental relative humidity, and (4) vertical wind shear. While this is not a complete list of environmental parameters that are relevant to cyclone genesis and intensification, they seem well suited to conclude on the large-scale tropical cyclone environment over the late Oligocene Eastern Tethys. Other environmental parameters associated with the genesis of tropical cyclones, e.g. low-level cyclonic shear vorticity (Wang et al., 2012), are difficult to evaluate from the geological record.

\subsubsection{Sea surface temperatures and geographic location}

Tropical cyclones develop only in regions where the SST is above $26.5^{\circ} \mathrm{C}$ and where the depth of the $26^{\circ} \mathrm{C}$ isotherm is $60 \mathrm{~m}$ or more below sea level (Gray, 1998). Most of them occur between $20^{\circ} \mathrm{N}$ and $20^{\circ} \mathrm{S}$ but none occur within about $2.5^{\circ}$ latitude of the equator (Gray, 1968). The late Oligocene Kachchh Basin was located at $11^{\circ} \mathrm{N}$ (Chatterjee et al., 2012) in the tropical cyclone belt and climate modelling suggests a generally higher Oligocene global SST than today due to a higher atmospheric $\mathrm{CO}_{2}$ concentration and a different global heat transport (von der Heydt and Dijkstra, 2006). Importantly, the studied sedimentary succession represents only sea level highstands (insolation maxima; Fig. 4). Eustatic sea level and climate are closely linked: as the climate warms the sea level rises due to the melting of the global ice sheets and as the seas warm, the ocean has more energy to generate tropical cyclone winds (Elsner et al., 2008). Moreover, the studied tempestite sequence was deposited in a globally warm climate interval at $\sim 27-24 \mathrm{Ma}$ (Late Oligocene Warming) when the long-term glaciation of Antarctica terminated (Zachos et al., 2001, 2008; von der Heydt and Dijkstra, 2006). This implies that the tropical Eastern Tethys had exceeded the SST threshold necessary for the development of strong cyclones during the time intervals represented by the Bermoti River section.

Nowadays, surface wind associated with a low-level southwesterly jet off the eastern coast of northern equatorial Africa (the Somali or East African jet) forces an offshore Ekman flow, upwelling along the coast of East Africa and the Arabian Peninsula, and cooling of the Arabian Sea during the height of the monsoon season (July-August; Evan and Camargo, 2011). Despite this wind-driven cooling of the western Arabian Sea, ocean surface temperatures over large parts of the basin remain, however, above the temperature threshold for cyclogenesis the entire year $\left(26.5^{\circ} \mathrm{C}\right)$, and most storms form in the eastern Arabian Sea, where surface temperatures are warmer (Evan and Carmago, 2011). Therefore, SST cooling in upwelling areas is supposed as negligible factor for tempestite deposition in the late Oligocene Kachchh Basin.

\subsubsection{Environmental relative humidity}

Environmental relative humidity is another critical factor of cyclogenesis (Hill and Lackmann, 2009). Modelling experiments suggest that the presence of dry air from the Sahara region may result in lower averaged humidity and weaker tropical cyclones in the Atlantic compared to the Pacific (Hill and Lackmann, 2009). Evan and Carmago (2011) mentioned also that the entrainment of dry desert air from the surrounding environment into any storm that entered the Persian Gulf overwhelm the effects of very warm sea surface water and low vertical wind shear. For the late Oligocene no data exist on air humidity over the Tethys Ocean. Potential sources for dry air were the Arabian and North African deserts. Accordingly, generalizing palaeoclimatic maps indicate a relative arid climate in North Africa and the Middle East region similar to the present-day situation (PALEOMAP website, 2012). John et al. (2003) considered also that episodes of Antarctic cooling (Mi events) probably resulted in a stronger thermal gradient between the Southern and Northern Hemisphere during the middle Miocene, which would have induced a northward shift of the ITCZ bringing moisture and rainfall to northern Africa. In contrast, the tropical rain belt would have been located further south over Africa during non-Mi event times like the Late Oligocene Warming. Otherwise, large parts of the Arabian Peninsula and Middle East region, which are covered by deserts at present-day, were part of the shallow-marine Tethyan Seaway during this time providing a source for humid oceanic air (Rögl, 1998; Popov et al., 2004). This applies also for large parts of central Asia, which were covered by the Paratethys Sea (Rögl, 1998; Popov et al., 2004). Desertification of this region was associated with the shrinkage of this shallow epicontinental sea in the Miocene (Ramstein et al., 1997). Therefore, tropical storm development over the late Oligocene Eastern Tethys was probably not limited by dry environmental air like in the Persian Gulf, which is only a relatively small, semi-enclosed body of water.

\subsubsection{Vertical wind shear}

Important pre-condition for cyclone formation is a largescale environment with small vertical wind shear (Gray, 1968). The strength of the vertical wind shear over the Arabian Sea is dependent on the strength of the Indian summer monsoon and the tropical easterly jet higher up in the atmosphere. The high-altitude winds flow from the opposite direction of the low-level monsoon winds creating a high vertical wind shear, which halts cyclone formation by blowing off the top of tropical storms (Hubert et al., 1983; Rao et al., 2008; Krishna, 2009). Weakening of the Indian summer monsoon is favorable for the formation of more severe tropical storms 


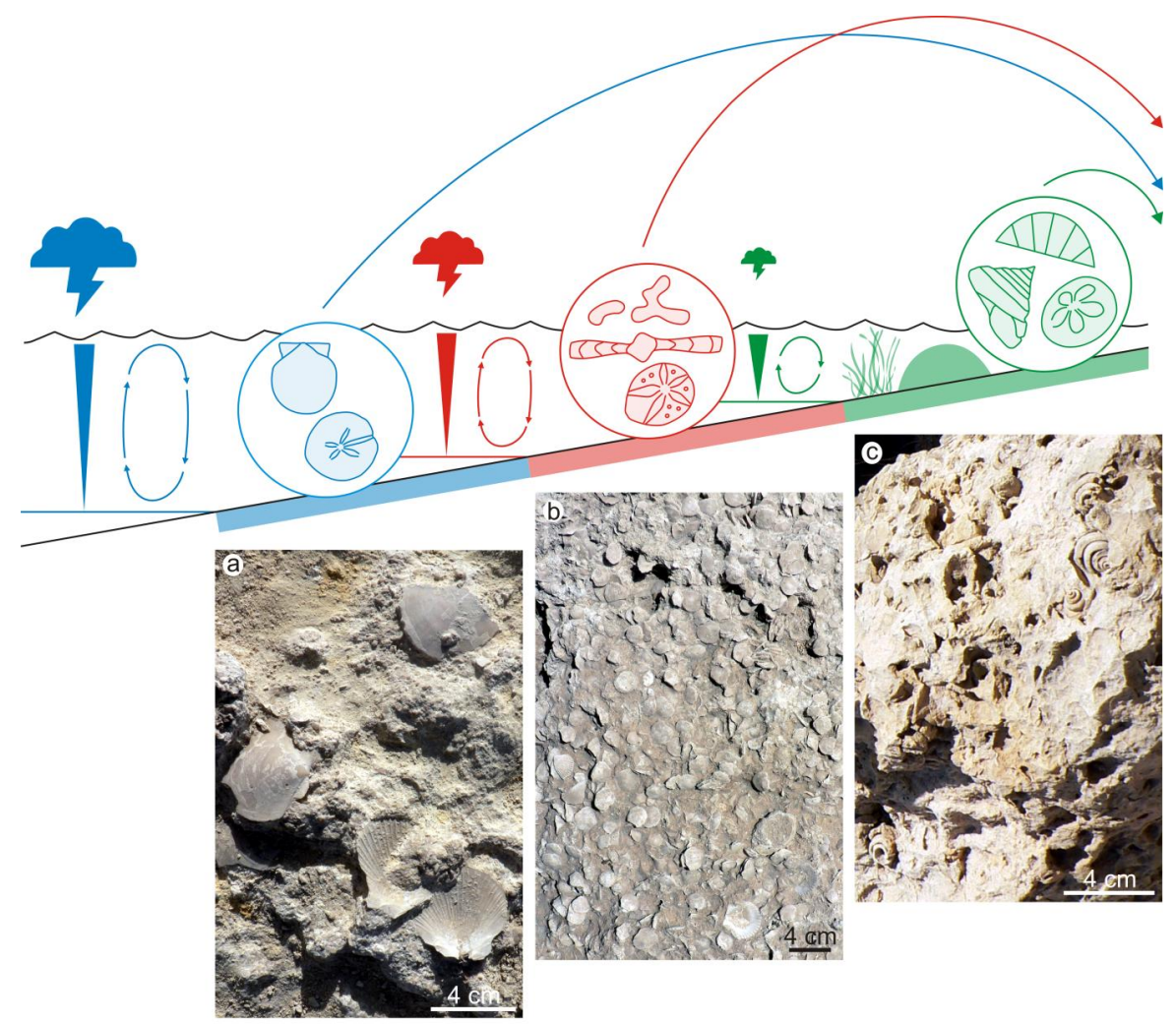

Fig. 5. Facies model for shallow-marine tempestite deposition on the Kachchh Mainland Uplift carbonate ramp illustrating the relationships of skeletal composition and storm intensity (cloud symbol: green $=$ weak, red = moderate, blue $=$ strong). The thick vertical arrowheads indicate the storm wave base depth; the symbols representing the defined tempestite biotic assemblages refer to Fig. 2. (a) Tempestites with abundant Amussiopecten represent the deepest storm wave base. (b) A moderately deep storm wave base is indicated by reworking and nearshore deposition of large lepidocyclinids. (c) Gastropod shell beds document storm reworking in shallow water.

because it is coupled to a decrease of the vertical wind shear (Rao et al., 2008; Evan et al., 2011).

The Indian monsoon is an integral part of the Asian monsoon system. Of greatest relevance to the strength of this large-scale atmospheric circulation is the land-sea thermal contrast that creates a vast low-pressure system over Central Asia during summer, drawing in warm and humid air from the Arabian Sea towards the Tibetan Plateau (Webster et al., 1998). Due to this thermal and further orographic controls Himalayan-Tibetan Plateau uplift since the Indo-Asia collision has been inferred to be the main force for the evolution of the Asian monsoon (e.g. Ruddiman and Kutzbach, 1989; Raymo and Ruddiman, 1992). Uplift of this area began $\sim 50 \mathrm{Ma}$ ago (Eocene) during the initial collision and was intensified during the early Miocene (Chatterjee et al., 2012). The onset of aeolian deposition on the Chinese Loess Plateau shows that the major change towards an Asian monsoon climate was achieved at $\sim 22 \mathrm{Ma}$ (early Miocene; Guo et al., 2002, 2008). Since then the overall trend is one of gradually increasing monsoon strength to $10 \mathrm{Ma}$ (late Miocene) with an unusually weak monsoon between 16.5 and $15 \mathrm{Ma}$ (Clift et al., 2008). The exact timing of the Tibetan Plateau uplift is, however, a matter of considerable debate (Wang et al., 2008). There is emerging evidence for regionally high Tibetan palaeoelevations early during the Indo-Asia collision indicating that an early plateau formation may have already contributed to monsoon intensification at the EoceneOligocene transition (Dupont-Nivet et al., 2008; Hoorn et al., 2012, further references therein). Consistently, it is hypothesised from the compilation of pollen data from China that the transition to the monsoon climate in East Asia occurred in the latest Oligocene (Sun and Wang, 2005). In line with this evidence, it is likely that vertical wind shear associated with an early monsoon circulation had affected cyclone formation over the late Oligocene Eastern Tethys.

\subsection{Monsoon impact on late Oligocene tropical cyclone trends}

The low palaeodepth gradients during the inundation episodes show that changing compositions of the skeletal assemblages in the tempestites of the Maniyara Fort Formation must reflect a shifting of the storm wave base rather than water depth fluctuations related to sea level changes. A shallow storm wave base is shown by the association of nearshore 


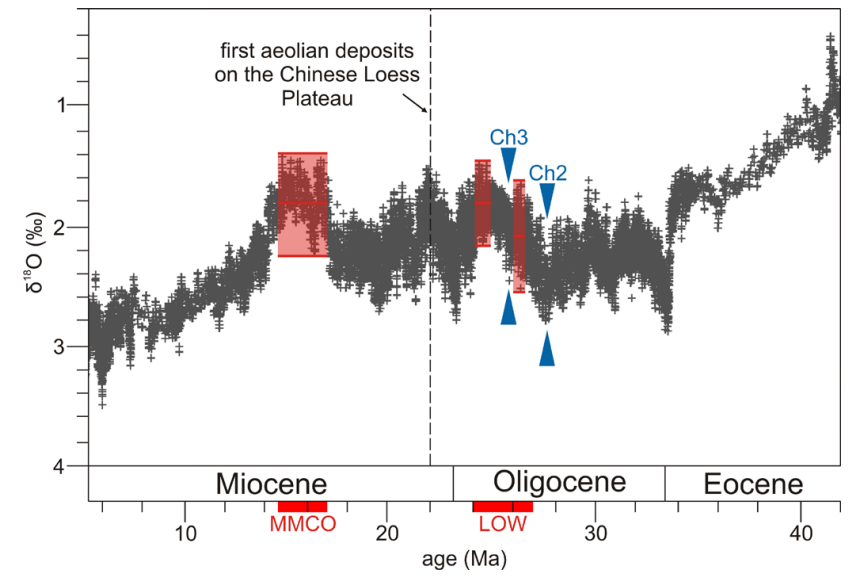

Fig. 6. Deep-sea benthic foraminiferal oxygen isotope curve as estimate for the Eocene-Miocene evolution of the global climate (modified after Zachos et al., 2008; LOW = Late Oligocene Warming, $\mathrm{MMCO}=$ Middle Miocene Climate Optimum). Blue arrowheads indicate the $\mathrm{Ch} 2$ and $\mathrm{Ch} 3$ sequence boundaries of Hardenbol et al. (1998). The onset of aeolian sedimentation on the Chinese Loess Plateau is considered as proof for the initiation of the Asian monsoon (Guo et al., 2002).

mollusc faunas with Clypeaster echinoids and reef corals (Fig. 5c). An intermediate depth of the storm wave base is indicated by mass accumulations of large lepidocyclinids with frequent Eupatagus echinoids and/or some amounts of corallinaceans (Figs. $3 \mathrm{f}$ and $5 \mathrm{~b}$ ). The deepest storm wave base is represented by the Amussiopecten-Schizaster assemblage (Fig. 5a). Despite of the incomplete stratigraphic record and relative low biostratigraphic resolution, we think that the section is suited to reconstruct long-term atmospheric variability from these storm wave base depth estimates as indicator for storm intensities. Regional effects and climate variability during a glaciation cycle are assumed as to be insignificant for this interpretation because it refers to a single outcrop, which records third-order sea level highstands only.

The larger benthic foraminiferal tempestite succession at the base of the Maniyara Fort Formation documents frequent storms of moderate intensities (Fig. 2) during the highstand of the third-order sea level cycle that follows on the Ru4/Ch1 sequence boundary of Hardenbol et al. (1998). A reduced storm activity is indicated for the next third-order sea level highstand by the decreased abundance of tempestite beds and their shallow wave base (Fig. 2). The highest storm activity is documented for the third-order sea level highstand after the Ch3 sequence boundary of Hardenbol et al. (1998) due to frequent storm beds and deep storm wave base depths estimates (Fig. 2). Principally, the winds over the Arabian Sea are considered as meaningful indicators for the strength of the Indian summer monsoon (Wang et al., 2003). Accordingly, the moderate tropical storm intensity during the first third-order sea level highstand points to a relatively low vertical wind shear over the Eastern Tethys due to the presence of a relatively weak monsoon. The reduced storm intensity and frequency during the following third-order sea level highstand indicates a strengthening of the monsoon and associated vertical wind shear. In contrast, a very weak or even absent monsoon might have favored the intensification of tropical storms during the third-order sea level highstand after the $\mathrm{Ch} 3$ sequence boundary of Hardenbol et al. (1998). A comparable decline of the monsoon over northern India and China has been recorded at 16.5-15 Ma in weathering records from the Arabian Sea, the Bay of Bengal and the South China Sea (Clift et al., 2008; Wan et al., 2010). It corresponds to the Middle Miocene Climate Optimum (MMCO; Fig. 6), when the global annual surface temperature was $\sim 3-4^{\circ} \mathrm{C}$ higher than today (You, 2010). Of greatest relevance to the strength of the Asian summer monsoon is the temperature over the Tibetan Plateau region because it provides source for heating in the lower atmosphere during summer that creates a vast low-pressure system over central Asia, drawing in warm and humid air from the Indian Ocean towards the plateau (SW monsoon; Goes et al., 2005). Weakening of the Tibetan Plateau surface sensible heat flux in a warming world is therefore expected to have a strong influence on certain regions of the Asian summer monsoon in which Tibetan Plateau thermal forcing plays an important role (Wu et al., 2012). Consistent with this, the strong decline of the monsoon over northern India during the MMCO has been interpreted to reflect a decreased temperature gradient between the tropical Indian Ocean and the Asian landmass (Reuter et al., 2012). Interestingly, the peak of storm activity in the Kachchh Basin correlates with the temperature maximum of the late Oligocene warm period at $\sim 24 \mathrm{Ma}$, which has a comparable $\delta^{18} \mathrm{O}$ range in the global deep-sea oxygen isotope record (Zachos et al., 2008) (Fig. 6). This oxygen isotope record provides not only constraints on the evolution of deep-sea temperature and continental ice volume but also represents a time-averaged record of high latitude SST because deep ocean waters derived primarily from cooling and sinking of water in polar regions (Zachos et al., 2001). It implies that the temperature maximum of the Late Oligocene Warming had a similar magnitude than that of the MMCO causing a weak thermal contrast between the tropical Tethys and the Asian continent. In contrast, the slightly heavier deep-sea oxygen isotope values during the temperature maximum of the previous third-order sea level cycle at $\sim 26 \mathrm{Ma}$ (Fig. 6) suggest that this global temperature rise was not high enough to prevent the Indian summer monsoon.

\section{Conclusions}

The Maniyara Fort Formation in the Kachcch Basin (NW India) comprises a succession of vast shell beds composed of larger benthic foraminifers, molluscs and echinoids that were deposited in an isolated inner ramp environment during the late Oligocene. Sediment deposition occurred only during 
third-order sea level highstands separated by long-lasting erosional gaps. The skeletal components represent a mixture of different marine environments documenting extensive sediment transport from deep to shallow water by severe tropical storms (cyclones). Three major biotic assemblages point to variable storm intensities: (1) shallow storm reworking is indicated by nearshore gastropods, Clypeaster echinoids and reef corals; (2) an intermediated storm wave base is reflected in larger benthic foraminiferal (lepidocyclinids) deposits with abundant Eupatagus echinoids and corallinacean algae; (3) a deep storm wave base caused high amounts of Amussiopecten bivalves and Schizaster echinoids in the tempestites. The intensity of tropical cyclones over the recent Arabian Sea is primarily controlled by the strength of the vertical wind shear, which is depending on the strength of the Indian summer monsoon. Accordingly, the reconstructed longterm storm intensity trends from the Maniyara Fort Formation are interpreted to reflect monsoon variability over northern India during the late Oligocene. For the third-order sea level highstand that follows on the $\mathrm{Ch} 2$ sequence boundary $(\sim 26 \mathrm{Ma})$ the low tempestite frequency and relative shallow storm wave base depth suggest already the action of a relative strong Indian monsoon. In contrast, a weak Indian monsoon is indicated for the next third-order sea level highstand ( $\sim 24 \mathrm{Ma}$ ) by frequent tempestites representing a deep storm wave base. This Indian monsoon decline correlates to the temperature maximum of the Late Oligocene Warming and implies that this global temperature rise had largely reduced the land-sea thermal contrast between the tropical Tethys and the Asian continent.

Acknowledgements. We are indebted to D. Banerjee (Delhi) for organizing the local contacts and the Bhatti family (Bhuj) for their great hospitality and logistic support. SanghiCement is thanked for free lodging and catering. B. Berning (Linz) attended field work, D. Bassi (Ferrara) kindly identified the larger benthic foraminifers and M. Gross (Graz) determined the ostracods. T. Wagner (Graz) created the digital elevation model. We appreciate the constructive comments of J. Eggenhuisen (Utrecht) and two anonymous reviewers. Funding by the FWF (Austrian Science Fund) through grants P23492 and P18189 is gratefully acknowledged.

Edited by: A. Sluijs

\section{References}

Ali, J. R. and Aitchison, J. C.: Gondwana to Asia: Plate tectonics, paleogeography and the biological connectivity of the Indian sub-continent from the Middle Jurassic through latest Eocene (166-35 Ma), Earth Sci. Rev., 88, 145-166, 2008.

Amorosi, A.: Detecting compositional, spatial, and temporal attributes of glaucony: a tool for provenance research, Sediment. Geol., 109, 135-153, 1997.

Bahlburg, H., Spiske, M., and Weiss, R.: Comment on "Sedimentary features of tsunami backwash deposits in a shallow marine
Miocene setting, Mejillones Peninsula, northern Chile", Sediment. Geol., 228, 77-80, 2010.

Bandel, K. and Wedler, E.: Hydroid, amphineuran and gastropod zonation in the littoral of the Caribbean Sea, Colombia, Senckenbergiana maritima, 19, 1-129, 1987.

Biswas, S. K.: Rift basins in the western margin of India and their hydrocarbon prospects, B. Am. Assoc. Petrol. Geol., 66, 14971513, 1982.

Biswas, S. K.: Regional tectonic framework, structure and evolution of the western marginal basins of India, Tectonophysics, 135, 307-327, 1987.

Biswas, S. K.: Tertiary stratigraphy of Kutch, J. Palaeont. Soc. India, 37, 1-29, 1992.

Biswas, S. K.: A review of structure and tectonics of Kutch Basin, western India, with special reference to earthquakes, Current Sci., 88, 1592-1600, 2005.

Biswas, S. K. and Deshpande, S. V.: Mode of eruption of Deccan Trap lavas with special reference to Kutch, J. Geol. Soc. India, 14, 134-141, 1973.

Biswas, S. K. and Raju, D. S. N.: Note on rock-stratigraphic classification on the Tertiary sediments of Kutch, Q. J. Geol. Min. Metall. Soc. India, 43, 177-180, 1971.

Brand, A. R.: Scallop ecology: distributions and behaviour, in: Scallops: Biology, Ecology and Aquaculture, edited by: Shumway, S. E. and Parsons, G. J., Dev. Aquaculture Fish. Sci., 35, 651-744, 2006.

Brandt, D. S. and Elias, R. J.: Temporal variations in tempestite thickness may be a geological record of atmospheric $\mathrm{CO}_{2}$, Geology, 17, 951-952, 1989.

Brett, C. E. and Seilacher, A.: Fossil Lagerstätten: a taphonomic consequence of event sedimentation, in: Cycles and Events in Stratigraphy, edited by: Einsele, G., Ricken, W., and Seilacher, A., Springer-Verlag, Berlin Heidelberg, 283-297, 1991.

Cahuzac, B. and Poignant, A.: Essai de biozonation de l'OligoMiocène dans les basins européens à l'aide des grands foraminifères nèritiques, Bull. Soc. Géol. Fr., 168, 155-169, 1997.

Charabi, Y. (Ed.): Preface, in: Indian Ocean Tropical Cyclones and Climate Change, Springer, Dordrecht, vii, 2010.

Chatterjee, S., Goswami, A., and Scotese, C. R.: The longest voyage: Tectonic, magmatic, and paleoclimatic evolution of the Indian plate during its northward flight from Gondwana to Asia, Gondwana Res., 23, 238-267, 2012.

Chave, K. E.: Skeletal durability and preservation, in: Approaches to Paleoecology, edited by: Imbrie, J. and Newell, N., Wiley, New York, 377-382, 1964.

Clift, P. D., Hodges, K. V., Heslop, D., Hannigan, R., van Long, H., and Calves, G.: Correlation of Himalayan exhumation rates and Asian monsoon intensity, Nat. Geosci., 1, 875-880, 2008.

de Ridder, C.: Clypeastérö̈des et spatangoïdes littoraux de Nouvelle-Calédonie (Echinodermata), Bull. Mus. Natl. Hist. Nat. Sect. A: Zool. Biol. Ecol. Anim., 6, 617-624, 1984.

Donato, S. V., Reinhardt, E. G., Boyce, J. I., Rothaus, R., and Vosmer, T.: Identifying tsunami deposits using bivalve shell taphonomy, Geology, 36, 199-202, 2008.

Dupont-Nivet, G., Hoorn, C., and Konert, M.: Tibetan uplift prior to the Eocene-Oligocene climate transition: Evidence from pollen analysis of the Xining Basin, Geology, 36, 987-990, 2008. 
El Albani, A., Meunier, A., and Fürsich, F.: Unusual occurrence of glauconite in a shallow lagoonal environment, Terra Nova, 17, 537-544, 2005.

Elsner, J. B., Kossin, J. P., and Jagger, T. H.: The increasing intensity of the strongest tropical cyclones, Nature, 455, 92-95, 2008.

Einsele, G., Chough, S. K., and Shiki, T.: Depositional events and their records-an introduction, Sediment. Geol., 104, 1-9, 1996.

Engel, M. and Bückner, H.: The identification of palaeo-tsunami deposits - a major challenge in coastal sedimentary research, Coastline Reports, 17, 65-80, 2011.

Emanuel, K. A., Sundarajan, R., and Williams, J.: Hurricanes and global warming: Results from downscaling IPCC AR4 simulations, B. Am. Meteorol. Soc., 89, 347-367, 2008.

Evan, A. T. and Carmago, S. J. A.: A climatology of Arabian Sea cyclonic storms, J. Climate, 24, 140-158, 2011.

Evan, A. T., Kossin, J. P., Chung, C., and Ramanathan, V.: Arabian Sea tropical cyclones intensified by emissions of black carbon and other aerosols, Nature, 479, 94-97, 2011.

Evan, A. T., Kossin, J. P., Chung, C. E., and Ramananthan, V.: Evan et al. reply, Nature, 489, E2-E3, doi:10.1038/nature11471, 2012.

Feldens, P., Schwarzer, K., Szczuciński, W., Stattegger, K., Sakuna, D., and Somgpongchaiykul, P.: Impact of 2004 tsunami on seafloor morphology and offshore sediments, Pakarang Cape, Thailand, Pol. J. Environ. Stud., 18, 63-68, 2009.

Flügel, E.: Microfacies of Carbonate Rocks: Analysis, Interpretation and Application, Springer-Verlag, Berlin Heidelberg, 2004.

Fujiwara, O. and Kamataki, T.: Identification of tsunami deposits considering the tsunami waveform: An example of subaquaeous tsunami deposits in Holocene shallow bay on southern Boso Peninsula, Central Japan, Sediment. Geol., 200, 295-313, 2007.

Gagan, M., Chivas, A. R., and Herczeg, A. L.: Shelf-wide erosion, deposition, and suspended sediment transport during cyclone Winifred, central Great Barrier Reef, Australia, J. Sediment. Petrol., 60, 456-470, 1990.

Guo, Z. T., Ruddiman, W. F., Hao, Q. Z., Wu, H. B., Qiao, Y. S., Zhu, R. X., Peng, S. Z., Wei, J. J., Yuan, B. Y., and Liu, T. S.: Onset of Asian desertification by $22 \mathrm{Myr}$ ago inferred from loess deposits in China, Nature, 416, 159-163, 2002.

Guo, Z. T., Sun, B., Zhang, Z. S., Peng, S. Z., Xiao, G. Q., Ge, J. Y., Hao, Q. Z., Qiao, Y. S., Liang, M. Y., Liu, J. F., Yin, Q. Z., and Wei, J. J.: A major reorganization of Asian climate by the early Miocene, Clim. Past, 4, 153-174, doi:10.5194/cp-4-1532008, 2008.

Goes, J. I., Thoppil, P. G., Gomes, H., and Fasullo, J. T.: Warming of the Eurasian landmass is making the Arabian Sea more productive, Science, 308, 545-547, 2005.

Goldenberg, S. B., Landsea, C., Mestas-Nunez, A. M., and Gray, W. M.: The recent increase in Atlantic hurricane activity, Science, 293, 474-479, 2001.

Gradstein, F. M., Ogg, J. G., Schmitz, M. D., and Ogg, G. M.: The Geologic Time Scale 2012, Elsevier, Amsterdam, 2012.

Gray, W. M.: Global view of the origin of tropical disturbances and storms, Mon. Weather Rev., 96, 669-700, 1968.

Gray, W. M.: The formation of tropical cyclones, Meteorol. Atmos. Phys., 67, 37-69, 1998.

Gunnell, Y., Gallagher, K., Carter, A., Widdowson, M., and Hurford, A. J.: Denudation history of the continental margin of western peninsular India since the early Mesozoioc - reconciling apatite fission-track data with geomorphology, Earth Planet. Sc.
Lett., 215, 187-201, 2003.

Hardenbol, J., Thierry, J., Farley, M. B., Jacquin, T., Graciansky, P.C., and Vail, P. R.: Mesozoic and Cenozoic sequence chronostratigraphic framework of European basins, in: Mesozoic and Cenozoic Sequence Stratigraphy of European Basins, edited by: Graciansky, C.-P., Hardenbol, J., Jacquin, T., and Vail, P. R., SEPM Special Publications, 60, 3-13, 1998.

Harzhauser, M., Reuter, M., Piller, W. E., Berning, B., Kroh, A., and Mandic, O.: Oligocene and Early Miocene gastropods from Kutch (NW-India) document an early biogeographic switch from Western Tethys to Indo-Pacific, Paläont. Z., 83, 333-372, 2009.

Henderson-Sellers, A., Zhang, H., Berz, G., Emanuel, K., Gray, W., Landsea, C., Holland, G., Lighthill, J., Shieh, S.-L., Webster, P., and McGuffie, K.: Tropical Cyclones and Global Climate Change: A Post-IPCC Assessment, B. Am. Meteorol. Soc., 79, 19-38, 1998.

Hendler, G., Miller, J. E., Pawson, D. E., and Kier, P. M.: Echinoderms of Florida and the Carribean, Smithsonian Institution Press, Washington, 1995.

Hill, K. A. and Lackmann, G. M.: Influence of environmental humidity on tropical cyclone size, Mon. Weather Rev., 137, 3294 3315, 2009.

Himmelman, J. H., Guderley, H. E., and Duncan, P. F.: Responses of the saucer scallop Amusium balloti to potential predators, J. Exp. Mar. Biol. Ecol., 378, 58-61, 2009.

Holland, G. J. and Webster, P. J.: Heigthened tropical cyclone acivity in the North Atlantic: Natural variability or climate trend?, Philos. T. Roy. Soc. A, 365, 2695-2716, 2007.

Hoorn, C., Straathof, J., Abels, H. A., Xu, Y., and Utescher, T.: A late Eocene palynological record of climate change and Tibetan Plateau uplift (Xining Basin, China), Palaeogeogr. Palaeocl., 344-345, 16-38, 2012.

Hubert, W. E., Hull, A. N., Morford, D. R., and Englebretson, R. E.: Forecasters Handbook for the Middle East/Arabian Sea. United States Navy, Naval Environmental Prediction Research Facility, Monterey, California, available at: http://www.nrlmry.navy.mil/ forecaster_handbooks/EastArabianSea/, 1983.

Jarvis, A., Reuter, H. I., Nelson, E., and Guevara, E.: Holefilled SRMT for the globe Version 4. CGIAR-CSI SRTM $90 \mathrm{~m}$ Database, available at: http://srtm.csi.cgiar.org/, 2008.

John, C. M., Mutti, M., and Adatte, T.: Mixed carbonate-siliciclastic record on the North African margin (Malta) coupling of weathering processes and mid Miocene climate, Geol. Soc. Am. Bull., 115, 217-229, 2003.

Jorry, S., Hasler, C.-A., and Davaud, E.: Hydrodynamic behavior of Nummulites: implications for depositional models, Facies, 52, 221-235, 2006.

Kanazawa, K.: Adaptation of test shape for burrowing and locomotion in spatangoid echinoids, Palaeontology, 35, 733-750, 1992.

Kidwell, S. M.: Taphonomic feedback (live/dead interactions) in the genesis of bioclastic beds: keys to reconstructing sedimentary dynamics, in: Cycles and Events in Stratigraphy, edited by: Einsele, G., Ricken, W., and Seilacher, A., Springer-Verlag, Berlin, 268-282, 1991.

Klotzbach, P. J.: Trends in global tropical cyclone activity over the past twenty years (1986-2005), Geophys. Res. Lett., 33, doi:10.1029/2006GL025881, 2006.

Knutson, T. R., McBride, J. L., Chan, J., Emanuel, K., Holland, G., Landsea, C., Held, I., Kossin, J. P., Srivastava, A. K., and Sugi, 
M.: Tropical cyclones and climate change, Nat. Geosci., 3, 157$163,2010$.

Kominz, M. A. and Pekar, S. F.: Oligocene eustasy from twodimensional sequence stratigraphic backstripping, Geol. Soc. Am. Bull., 113, 291-304, 2001.

Kominz, M. A., Browning, J. V., Miller, K. G., Sugarman, P. J., Mizintseva, S., and Scotese, C. R.: Late Cretaceous to Miocene sea-level estimates from the New Jersey and Delaware coastal plain coreholes: an error analysis, Basin Res., 20, 211-226, 2008.

Kornicker, L. S.: Ecology and taxonomy of Recent Bairdiinae (Ostracoda), Micropaleontology, 7, 55-70, 1961.

Kortekaas, S. and Dawson, A. G.: Distinguishing tsunami and storm deposits: An example from Martinhal, SW Portugal, Sediment. Geol., 200, 208-221, 2007.

Krishna, K. M.: Intensifying tropical cyclones over the North Indian Ocean during summer monsoon - global warming, Global Planet. Change, 65, 12-16, 2009.

Long, D. G. F.: Tempestite frequency curves: a key to Late Ordovician and Early Silurian subsidence, sea-level change, and orbital forcing in the Anticosti foreland basin, Quebec, Canada, Can. J. Earth Sci., 44, 413-431, 2007.

Mandic, O. and Piller, W. E.: Pectinid coquinas and their palaeoenvironmental implications - examples from the early Miocene of northeastern Egypt, Palaeogeogr. Palaeocl., 172, 171-191, 2001.

Miller, K. G., Kominz, M. A., Browning, J. V., Wright, J. D., Mountain, G. S., Katz, M. E., Sugarman, P. J., Cramer, B. S., ChristieBlick, N., and Pekar, S. F.: The Phanerozoic record of global sea-level change, Science, 310, 1293-1298, 2005.

Mortensen, T.: A Monograph of the Echinoidea. V, 2. Spatangoida II. Amphisternata II. Spatangidæ, Loveniidæ, Pericosmidæ, Schizasteridæ, Brissidae, C.A. Reitzel, Copenhagen, 1951.

Morton, R. A., Gelfenbaum, G., and Jaffe, B. E.: Physical criteria for distinguishing sandy tsunami and storm deposits using modern examples, Sediment. Geol., 200, 184-207, 2007.

Nebelsick, J. H. and Kroh, A.: The stormy path of life to death assemblages: The formation and preservation of mass accumulations of fossil sand dollars, Palaios, 17, 378-393, 2002.

Nigam, R. and Chaturvedi, S. K.: Do inverted depositional sequences and allochthonous foraminifers in sediments along the Coast of Kachchh, NW India, indicate palaeostorm and/or tsunami effects?, Geo-Mar. Lett., 26, 42-50, 2006.

PALEOMAP website: available at: http://www.scotese.com/, last access: 12 December 2012.

Pedley, M.: A review of sediment distributions and processes in Oligo-Miocene ramps of southern Italy and Malta (Mediterranean divide), in: Carbonate Ramps, edited by: Wright, V. P. and Burchette, T. P., Geol. Soc. London Spec. Publ., 149, 163-179, 1998.

Popov, S. V., Rögl, F., Rozanov, A. Y., Steininger, F. F., Sherba, I. G., and Kovac, M.: Lithological-Palaeogeographic maps of Paratethys, 10 maps Late Eocene to Pliocene, Cour. Forsch.-Inst. Senckenberg, 250, 1-46, 2004.

Puga-Bernabéu, Á., Martín, J. M., and Braga, J. C.: Tsunami-related deposits in temperate carbonate ramps, Sorbas Basin, southern Spain, Sediment. Geol., 199, 107-127, 2007.

Ramstein, G., Fluteau, F., Besse, J., and Joussaume, S.: Effect of orogeny, plate motion and land-sea distribution on Eurasian climate change over the past 30 million years, Nature, 386, 788$795,1997$.
Rao, V. B., Ferreira, C. C., Franchito, S. H., and Ramakrishna, S. S. V. S.: In a changing climate weakening tropical easterly jet induces more violent tropical storms over the north Indian Ocean, Geophys. Res. Lett., 35, L15710, 2008.

Rasser, M. W. and Riegl, B.: Holocene coral reef rubble and its binding agents, Coral Reefs, 21, 57-72, 2002.

Raymo, M. E. and Ruddiman, W. F.: Tectonic forcing of late Cenozoic climate, Nature, 359, 117-122, 1992.

Reuter, M., Piller, W. E., Harzhauser, M., Kroh, A., and Bassi, D.: Termination of the Arabian shelf sea: stacked cyclic sedimentary patterns and timing (Oligocene/Miocene, Oman), Sediment. Geol., 212, 12-24, 2008.

Reuter, M., Kern, A. K., Harzhauser, M., Kroh, A., and Piller, W. E.: Global warming and South Indian monsoon rainfalllessons from the Mid-Miocene, Gondwana Res., 23, 1172-1177, doi:10.1016/j.gr.2012.07.015, 2012.

Risi, A., Wanless, H. R., Tedesco, L. P., and Gelsanliter, S.: Catastrophic sedimentation from Hurricane Andrew along the Southwest Florida Coast, J. Coastal Res., 21, 83-102, 1995.

Rögl, F.: Paleogeographic considerations for Mediterranean and Paratethys seaways (Oligocene to Miocene), Ann. Naturhist. Mus. Wien Ser. A, 99, 279-310, 1998.

Ruddiman, W. F. and Kutzbach, J. E.: Forcing of late Cenozoic northern hemisphere climate by plateau uplift in southern Asia and American west, J. Geophys. Res., 94, 409-427, 1989.

Saunders, A. D., Jones, S. M., Morgan, L. A., Pierce, K. L., Widdowson, M., and Xu, Y. G.: Regional uplift associated with continental large igneous provinces: The role of mantle plumes and the lithosphere, Chem. Geol., 241, 282-318, 2007.

Schinner, G. O.: Burrowing behaviour, substratum preference, and distribution of Schizaster canaliferus (Echinoidea: Spatangoida) in the Northern Adriatic Sea, Mar. Ecol., 14, 129-145, 1993.

Schultz, H.: Sea Urchins: a guide to worldwide shallow water species, Heinke \& Peter Schultz Partner, Hemdingen, 2005.

Schultz, H.: Sea Urchins II: worldwide irregular deep water species, Heinke \& Peter Schultz Partner, Hemdingen, 2009.

Seilacher, A. and Aigner, T.: Storm deposition at the bed, facies, and basin scale: the geological perspective, in: Cycles and Events in Stratigraphy, edited by: Einsele, G., Ricken, W., and Seilacher, A., Springer-Verlag, Berlin Heidelberg, 249-267, 1991.

Sepkowski Jr., J. J., Bambach, R. K., and Droser, M. L.: Secular changes in Phanerozoic event bedding and biological overprint, in: Cycles and Events in Stratigraphy, edited by: Einsele, G., Ricken, W., and Seilacher, A., Springer-Verlag, Berlin Heidelberg, 298-312, 1991.

Shanker, R.: Seismotectonics of Kutch rift basin and its bearing on the Himalayan seismicity, ISET Journal of Earthquake Technology, 38, 59-65, 2001.

Sheth, H. C.: Plume-related regional pre-volcanic uplift in the Deccan Traps: Absence of evidence, evidence of absence, in: Plates, Plumes and Planetary Processes, edited by: Foulger, G. R. and Jurdy, D. M., Geol. Soc. Am. Spec. Pap., 430, 785-813, 2007.

Solomon, S., Qin, D., Manning, M., Chen, Z., Marquis, M., Averyt, K. B., Tignor, M., and Miller, L.: Contribution of Working Group I to the Fourth Assessment Report of the Intergovernmental Panel on Climate Change, Cambridge University Press, Cambridge, 2007.

Stocchi, P., Escutia, C., Houben, A. J. P., Vermeersen, B. L. A., Bijl, P. K., Brinkhuis, H., DeConto, R. M., Galeotti, S., Passchier, S., 
Pollard, D., and IODP Expedition 318 scientists: Relative sealevel rise around East Antarctica during Oligocene glaciations, Nat. Geosci., 6, 380-384, 2013.

Sun, X. and Wang, P.: How old is the Asian monsoon system? Palaeobotanical records from China, Palaeogeogr. Palaeocl., 222, 181-222, 2005.

Valeton, I.: Saprolite-bauxite facies of ferralitic duricrusts on palaeosurfaces of former Pangaea, in: Palaeoweathering, palaeosurfaces, and related continental deposits, edited by: Thiry, M. and Simon-Coinçon, R., IAS Spec. Publ., 27, 153-188,1999.

Valeton, I. and Wilke, F.: Tertiary bauxites in subsidence areas and associated laterite-derived sediments in northwestern India, Contributions to Sedimentology, 18, 1-104, 1993.

Van Sickel, W. A., Kominz, M. A., Miller, K. G., and Browning, J. V.: Late Cretaceous and Cenozoic sea-level estimates backstripping analysis of borehole data, Onshore New Jersey, Basin Res., 16, 451-465, 2004.

Vecchi, G. A. and Knutson, T. R.: On estimates on historical North Atlantic tropical cyclone activity, J. Climate, 21, 3580-3600, 2008.

von der Heydt, A. and Dijkstra, H. A.: Effect of ocean gateways on the global ocean circulation in the late Oligocene and early Miocene, Paleoceanography, 21, PA1011, doi:10.1029/2005PA001149, 2006.

Wan, S., Clift, P. D., Li, A., Li, T., and Yin, X.: Geochemical records in the South China Sea: implications for East Asian summer monsoon evolution over the last $20 \mathrm{Ma}$, in: Monsoon Evolution and Tectonics - Climate linkage in Asia, edited by: Clift, P. D., Tada, R., and Zheng, H., Geol. Soc. London Spec. Publ., 342, 245-263, 2010.

Wang, B., Clemens, S. C., and Liu, P.: Contrasting the Indian and East Asian monsoons: implications on geological timescales, Mar. Geol., 201, 5-21, 2003.
Wang, B., Xu, S., and Wu, L.: Intensified Arabian Sea tropical storms, Nature, 489, E1-E2, doi:10.1038/nature11470, 2012.

Wang, Y., Wang, X., Xu, Y., Zhang, C., Li, Q., Tseng, Z. J., Takeuchi, G., and Deng, T.: Stable isotopes in fossil mammals, fish and shells from Kunlun Pass Basin, Tibetan Plateau: Paleoclimatic and paleo-elevation implications, Earth Planet. Sc. Lett., 270, 73-85, 2008.

Wanless, H. R., Tedesco, L. P., and Tyrell, K. M.: Production of subtidal tubular and surficial tempestites by Hurricane Kate, Caicos Platform, British West Indies, J. Sediment. Petrol., 58, 739-750, 1988.

Webster, P. J., Magana, V. O., Palmer, T. N., Shukla, J., Tomas, R. A., Yanai, M., and Yasunari, T.: Monsoons: processes, predictability, and the prospects for prediction, in the TOGA decade, J. Geophys. Res., 103, 14451-14510, 1998.

Webster, P. J., Holland, G. J., Curry, J. A., and Chang, H.-R.: Changes in tropical cyclone number, duration and intensity in a warming environment, Science, 309, 1844-1846, 2005.

Wu, G., Liu, Y., He, B., Bao, Q., Duan, A., and Jin, F.-F.: Thermal controls on the Asian summer monsoon, Scientific Reports, 2, 404, doi:10.1038/srep00404, 2012.

You, Y.: Climate-model evaluation of the contribution of sea-surface temperature and carbon dioxide to the Middle Miocene Climate Optimum as a possible analogue of future climate change, Aust. J. Earth Sci., 57, 207-219, 2010.

Zachos, J., Pagani, M., Sloan, L., Thomas, E., and Billups, K.: Trends, rhythms, and aberrations in global climate $65 \mathrm{Ma}$ to present, Science 292, 686-693, 2001.

Zachos, J. C., Dickens, G. R., and Zeebe, R. E.: An early Cenozoic perspective on greenhouse warming and carbon-cycle dynamics, Nature, 451, 279-283, 2008. 